\title{
ACADEMIC DISHONESTY AND PERSONALITY: AN ANALYSIS OF UNIVERSITY STUDENTS IN KARACHI, PAKISTAN
}

\author{
Amena Zehra Ali ${ }^{*}$ \\ Bushra Khan ** \\ Maryam Siddiqui***
}

\begin{abstract}
Academic dishonesty that involves the use of any prohibited means for gaining unfair advantage academically has become a global problem in educational institutions. Limited studies have been conducted to explore the significance of personality with reference to academic misconduct. The present study was conducted to find out the different personality correlates as well as predictors of Academic Dishonesty. For this purpose 232 students of undergraduate and graduate courses from different faculties of University of Karachi, Pakistan, with ages ranging between 18-35 years $\left(X^{-}=21.55, S D=2.44\right)$ participated in the study. Big Five Inventory $(B F I-44)^{l}$ was used to measure personality and English version of Academic Dishonesty Tendency Scale was used to measure academic dishonesty. Also five questions were developed to measure one more dimension of academic dishonesty which has been observed in local universities i.e., the tendency towards influencing teachers. For statistical analysis, correlation and regression analysis were conducted. Some personality types were found to be associated, and predictors of different dimensions of academic dishonesty.
\end{abstract}

Keywords: Academic dishonesty, extraversion, agreeableness, conscientiousness, neuroticism, openness to experience

\section{Introduction}

Academic dishonesty, also known as academic misconduct may broadly be defined as any prohibited means of gaining unfair advantage academically. ${ }^{3}$ It has become a global problem in educational set-ups, whether high school, college or university/ professional education. Academic dishonesty can include the following: cheating, using unauthorized material to achieve a gain in academic assignments, or having someone else do the work for you. It can also include fabrication, where one falsify or invent new information and not referencing appropriately. It can also include helping someone else copy off your work. Plagiarism is one of the most well-known forms of academic dishonesty, using

\footnotetext{
"AmenaZehra Ali, Ph.D. Associate Professor, Department of Psychology, University of Karachi

*** Bushra Khan, Ph.D. Assistant Professor, Department of Psychology, University of Karachi

**** Maryam Siddiqui, Ph.D. student, Institute of Clinical Psychology, University of Karachi

${ }^{1}$ John, O.P, Donahue, E.M, and Kentle, R.L, “The Big Five Inventory--Versions 4a and 5a.”(Berkeley:

University of California, Berkeley, Institute of Personality and Social Research, 1991).

${ }^{2}$ Eminoğlu, E, Nartgün, Z,

"Üniversiteöğrencilerininakademiksahtekarlıkeğilimlerininölçülmesineyönelikbirölçekgeliștirmeçalıșması."

UluslararasıİnsanBilimleriDergisi 6:1 (Bağlantıda, 2009).

${ }^{3}$ Mullens, A, "Cheating to Win." 41, No.10 (University Affairs, 2000): 22-28.
} 
ideas of another writer without referencing them. Dishonesty is something which is seen on every level of academia, whether it be elementary or graduate school. It has been described as an "epidemic"4 a "perennial problem" and "one of the major problems in education today".

The big five model of personality is one of the means through which a person can filter who is more likely to indulge in academic dishonesty as compared to others. The big five personality traits, which are in themselves broad categories, are the following, ${ }^{7}$ Extraversion, which is being excitable, social, talkative and assertive as well as having high amounts of expressiveness. Agreeableness is being sociable, kind and indulging in pro-social behaviors. Conscientiousness is being goal directed, organized and thoughtful, while neuroticism is being emotionally unstable, anxious and irritable. Finally, there is openness, where a person indulges in imagination and insight as well as having a broad range of interests.

One of the most prevalent means of academic dishonesty is using material available on the internet to plagiarize and fabricate content. When misuse of the internet for academic achievement was put together with the big five personality traits, it was seen that agreeableness, conscientiousness and emotional stability are all significantly and negatively correlated with internet based academic misconduct. ${ }^{8}$

In another study to understand the dynamics of personality in relation to academic dishonesty, extraversion was seen to dominate most of all in terms of academic dishonesty. ${ }^{9}$ In addition, it was seen that neuroticism is significantly associated with plagiarism and fraud, while conscientiousness was significantly and negatively correlated. ${ }^{10}$ In fact, this personality trait was strongly and positively correlated with being academically successful, honest and being able to achieve. ${ }^{11}$ In summary, when the big five model is taken into account, extraversion is most likely to lead to academic dishonesty, especially due to the excitable behavior since that is linked to risk taking behavior. Most students are very well aware of the consequences of academic dishonesty and yet choose to engage in it, which makes the dominant trait of excitability most likely

\footnotetext{
${ }^{4}$ Haines, V.J Diekhoff, G.M, LaBeff, E.E, and Clark, RE, "College cheating: Immaturity, lack of commitment and the neutralizing attitude." Research in Higher Education 25, No.4 (1986): 342-354.

${ }^{5}$ Davis, S.F, Grover, C.A, Becker, A.H, and McGregor, L.N, “Academic dishonesty: Prevalence, determinants, techniques, and punishments.” Teaching of Psychology 19, No.1 (1992):16-20.

${ }^{6}$ Singhal, A.C, "Factors in students dishonesty." Psychological Reports 51, No.3 (1982): 775-780.

${ }^{7}$ Goldberg, L. R, "Language and individual differences: The search for universals in personality lexicons." Review of Personality and Social Psychology 2, No. 1 (1981): 141-165.

${ }^{8}$ Karim, Zamzuri, Nor, Hidayah\&Shariza, "Exploring the relationship between Internet ethics in university students and the big five model of personality." Computers and Education 53, No.1 (2006): 86 - 93.

${ }^{9}$ Aslam, M.S, and Nazir, M.S, “Academic dishonesty and perceptions of Pakistani Students." International Journal of Education Management 24, No.7 (2010): 655-688.

${ }^{10}$ Giluk, T.L, and Postlethwaite, B.E, "Big Five personality and academic dishonesty: A meta-analytic review." Journal of Personality and Individual Differences 72, (2015): 59-67.

${ }^{11}$ Chamorro-Premuzic, T, and Furnham, A, "Personality, predicts academic performance: Evidence from two longitudinal university samples." Journal of Research in Personality 37, No.4 (2003): 319-338.
} 
to indulge in misconduct. ${ }^{12}$ The problem is that since most students indulge in such behavior, they mostly see it as a normative behavior.

Scheers and Dayton ${ }^{13}$ highlighted certain acts in academic dishonesty like lying to a teacher to avoid exam or about the originality of a paper. They have also mentioned about bribing teacher in exchange for grades. The reasons for academic dishonesty identified by different researchers includes along with others, the aims for better grades. This aim usually causes pressure on the student, and when parental and peer perspective is involved, this pressure tends to increase. According to Wein ${ }^{14}$, the student hopes and wishes to be able to satisfy their parents. Mostly the student cheats to improve their GPA. So there is "cut throat competition" among students to prove they are better than others even if this involves using unfair means. ${ }^{15}$ Influencing the teacher is usually the last resort taken, after trying all the other modes of dishonesty. This way the student is able to keep their positive images in the eyes of their peer group or even improve (when they use this mode in front of their peers). This type of dishonesty is generally not the focus of most researches on the topic.

Keeping in view the current scenario, where the ethics of people are even defined as whatever feels right is right, the present study was planned. In Pakistan, with time we see an increase in the incidents of cheating and other forms of dishonesty among students. It has been observed that not only do these acts of dishonesty has increased, but also the guilt or shame regarding these is reduced in students. While going over the literature, one thing that was found missing was the attitude of the student towards the teacher, especially for getting better grades. In Pakistan, it is a very common practice to influence the teacher by either threatening or sympathy seeking attitude. Keeping this in mind, the purpose of the present study became two-fold. Along with finding the predicting personality factors for academic dishonesty, a questionnaire was also developed to study this variable from the perspective of influencing the teacher.

In the light of the literature review, it was hypothesized that

a) There will be a correlation between big five personality types and different dimensions of academic dishonesty.

b) There will be a correlation between big five personality types and influencing teachers for grades.

c) Personality types will predict the type of academic dishonesty students are indulged in.

\footnotetext{
${ }^{12}$ Anderman, E. M, and Murdock, T.B. "Psychology of academic cheating," (San Diego California: Elsevier Academic Press, 2007).

${ }^{13}$ Scheers, N, and Dayton, M, "Improved Estimation of Academic Cheating Behavior Using the Randomized Response Technique.” Research in Higher Education 26, No.1 (1987): 61-69.

${ }^{14}$ Wein, E. Cheating: Risking it all for grades. Arizona Daily Wildcat.(1994)pp. 1

${ }^{15}$ Deep,K, Sahu, S, and Kalia, A.K, “ Academic Dishonesty: Some Discernible Trends.” Psychology of Education ( Global Vision Publishing House, 2007).
} 


\section{Method}

\section{Sample}

A sample of 232 students of undergraduate and graduate courses was taken conveniently from different faculties of University of Karachi, Pakistan. Out of these students, 107 were males and 125 were females. The age range of the sample was between 18-35 years $(\bar{X}=21.55, \mathrm{SD}=2.44)$. Only regular students from both morning and evening program of University of Karachi were selected for the present study.

\section{Material}

\section{Demographic information questionnaire}

A demographic information questionnaire was developed to measure the age, gender, class and other relevant socio-demographic information about the participants. The questionnaire was deliberately kept anonymous, since the issue of academic dishonesty was being measured in the study.

\section{Academic Dishonesty Tendency Scale (6 $^{16}$}

English version of the Academic Dishonesty Tendency Scale was used to measure the tendency of the test-takers for being dishonest in different scenarios. It is a 22 item questionnaire with the scoring on a 5-point rating scale. It consists of 4 subscales namely; Tendency Towards Cheating (5 items), Tendency Towards Dishonesty in Assignments (7 items), Tendency Towards Dishonesty in Research and Report (4 items) and Tendency Towards Dishonesty in Ascription (6 items). The Cronbach $\alpha$ internal consistency reliability coefficient of the scale is 0.71 for the first factor; 0.821 for the second factor; 0.785 for the third factor; 0.776 for the fourth factor and 0.90 for the scale as a whole. The test-retest reliability level of the scale was also calculated with an interval of 15 day sand the correlation was 0.88 . The construct validity of the scale was tested with explanatory and confirmatory factor analysis.

\section{Questionnaire to measure Dishonesty by Influencing Teachers}

A new 5-item questionnaire was developed to measure the Dishonesty students show by Influencing teachers. It is scored on a 5-point rating scale. It is designed to measure tendency like sympathy-seeking, threatening or pressurizing the teacher to pass or improve grades, as these are the common ways for influencing any teacher for better grades. It included items like "Students should not send any political activist to a teacher to make sure that they pass exam or get better grades", "It is reasonable for a student, who has performed poorly in an examination, to threaten the teacher for more marks", or "It is ethical for a student to cry or give emotional excuses to the teacher, if they have not performed well in an examination". Three out the five items were positively worded.

\footnotetext{
${ }^{16}$ Eminoğlu, E, Nartgün, Z,

"Üniversiteöğrencilerininakademiksahtekarlıkeğilimlerininölçülmesineyönelikbirölçekgeliştirmeçalışması."

UluslararasıİnsanBilimleriDergisi 6:1 (Bağlantıda, 2009).
} 
Items were checked for content relevance and were piloted on 50 students before including in this study

\section{Big Five Inventory (BFI-44) ${ }^{17}$}

A44-item version of Big Five Inventory was used. It is a self-report inventory that is designed to measure the five major personality types, namely; Openness to Experience, Conscientiousness, Extraversion, Agreeableness, and Neuroticism. The BFI-44 scales and longer version of Big Five have significant convergent and discriminant validity. BF-44 has good internal consistency and retest reliability. Cronbach Alpha co-efficient of .80 and a test re-test reliability of .85 on 3-months interval were obtained by John et. al., (1991).

\section{Procedure}

Using the purposive sampling method, students were approached individually from various faculties of University of Karachi, Pakistan. After explaining them about the purpose of the study, they were informed about their right for voluntary participation and were also ensured about the anonymity and confidentiality of their responses. All those who agreed to participate, were given the questionnaires to fill up, and then they were thanked for their participation. The researcher was present throughout the data collection, to handle any questions or queries that the participants might have.

\section{Results}

For the statistical analysis of the data, the scores were entered in SPSS v.21. Relationship between the big five personality traits and academic dishonesty was figured out by applying Pearson's correlation. Further, multiple regression analysis was also applied to see how strong a predictor the personality factors are for the different dimensions of academic dishonesty.

Table 1

\section{Correlations of Big Five Personality with different dimensions of academic} dishonesty including new dimension of influencing teachers

\begin{tabular}{|c|c|c|c|c|c|}
\hline & $\begin{array}{c}\text { Tendenc } \\
\mathbf{y} \\
\text { towards } \\
\text { cheating }\end{array}$ & $\begin{array}{c}\text { Tendency } \\
\text { towards } \\
\text { dishonesty } \\
\text { in } \\
\text { assignment } \\
\mathbf{S}\end{array}$ & $\begin{array}{c}\text { Tendency } \\
\text { towards } \\
\text { dishonest } \\
\mathbf{y} \text { in } \\
\text { research } \\
\text { \& reports }\end{array}$ & $\begin{array}{c}\text { Tendency } \\
\text { towards } \\
\text { dishonesty } \\
\text { in } \\
\text { ascription } \\
\text { s }\end{array}$ & $\begin{array}{c}\text { Dishonesty } \\
\text { by } \\
\text { Influencin } \\
\text { g Teachers }\end{array}$ \\
\hline Extraversion & -.084 & -.093 & $-.192 * *$ & $-.169 * *$ & $-.219 * *$ \\
$(.003)$ & $(.010)$ & $(.001)$ \\
\hline Agreeableness & $-.270 * *$ & $-.157 *$ & -.116 & $-.144 *$ & $-.269 * *$ \\
& $(.000)$ & $(.017)$ & $(.078)$ & $(.028)$ & $(.000)$ \\
\hline
\end{tabular}

\footnotetext{
${ }^{17}$ John, O.P, Donahue, E.M, and Kentle, R.L, Op.cit.
} 


\begin{tabular}{|c|c|c|c|c|c|}
\hline $\begin{array}{c}\text { Conscientiousnes } \\
\text { S }\end{array}$ & $\begin{array}{c}-.158^{*} \\
(.016)\end{array}$ & $\begin{array}{c}-.167 * \\
(.011)\end{array}$ & $\begin{array}{c}-.283^{* *} \\
(.000)\end{array}$ & $\begin{array}{c}-.112 \\
(.089)\end{array}$ & $\begin{array}{c}-.100 \\
(.128)\end{array}$ \\
\hline Neuroticism & .072 & .086 & .071 & .005 & -.004 \\
& $(.274)$ & $(.191)$ & $(.279)$ & $(.994)$ & $(.995)$ \\
\hline Openness to & $-.259^{* *}$ & $-.187 * *$ & $-.223^{* *}$ & $-.172 * *$ & $-.336^{* *}$ \\
Experience & $(.000)$ & $(.004)$ & $(.001)$ & $(.009)$ & $(.000)$ \\
\hline
\end{tabular}

$* \mathrm{p}<.05, * * \mathrm{p}<.01$

Table 1 shows correlations among all types of academic dishonesty assessed in the study with the Big Five personality traits. Openness to Experience showed a significant and negative relationship $(\mathrm{p}<.01)$ with all types of academic dishonesty. Extraversion, Agreeableness and Conscientiousness also correlates significantly with only certain types of academic dishonesty. Some of these correlations are more significant $(\mathrm{p}<.01)$ than others ( $\mathrm{p}<.05)$, but all these are negative correlations, indicating an increase in one variable is followed by a decrease in the other. However, neuroticism has an insignificant correlations ( $p>.05)$ with all types of academic dishonesty.

Table 2

Multiple regression analysis of the Big Five Personality in predicting the different factors of academic dishonesty

\begin{tabular}{|c|c|c|c|c|c|c|c|c|c|c|c|c|}
\hline & \multicolumn{3}{|c|}{$\begin{array}{c}\text { Tendency towards } \\
\text { Cheating }\end{array}$} & \multicolumn{3}{|c|}{$\begin{array}{l}\text { Tendency towards } \\
\text { Dishonesty in } \\
\text { Assignments }\end{array}$} & \multicolumn{3}{|c|}{$\begin{array}{l}\text { Tendency } \\
\text { towards } \\
\text { Dishonesty in } \\
\text { Research and } \\
\text { Report }\end{array}$} & \multicolumn{3}{|c|}{$\begin{array}{l}\text { Tendency } \\
\text { towards } \\
\text { Dishonesty } \\
\text { Ascription }\end{array}$} \\
\hline Variable & $B$ & SE B & $\beta$ & B & SE B & $\beta$ & B & \begin{tabular}{c|}
$\mathrm{SE}$ \\
$\mathrm{B}$
\end{tabular} & $\beta$ & $B$ & $\begin{array}{l}S E \\
B\end{array}$ & $\beta$ \\
\hline $\begin{array}{c}\text { Neuroti- } \\
\text { cism }\end{array}$ & .039 & .050 & .052 & .044 & .046 & .064 & .008 & .035 & .014 & -.015 & .045 & -.022 \\
\hline $\begin{array}{c}\text { Extraver } \\
\text { sion }\end{array}$ & -.001 & .057 & -.002 & -.034 & .052 & $\begin{array}{l}-.044 \\
\end{array}$ & $\begin{array}{l}.062 \\
\end{array}$ & .040 & -.104 & $-.10 才$ & .051 & -.141 * \\
\hline $\begin{array}{c}\text { Open- } \\
\text { ness }\end{array}$ & -.096 & .046 & -.142 & -.089 & .042 & -.147 * & -.069 & .032 & -.145 & -.039 & .042 & -.066 \\
\hline $\begin{array}{c}\text { Agree- } \\
\text { ableness }\end{array}$ & -.168 & .052 & -.22 *** & -.039 & $.04 \lambda$ & -.056 & .003 & .036 & .005 & -.065 & .047 & -.096 \\
\hline $\begin{array}{c}\text { Conscie } \\
\text { ntiousne } \\
\text { ss }\end{array}$ & -.025 & .053 & -.033 & -.047 & .049 & -.068 & -.104 & .037 & $-.19 * *$ & -.019 & .048 & -.028 \\
\hline $\mathbf{R}^{2}$ & & & .097 & & & .056 & & & .101 & & & .052 \\
\hline $\mathbf{F}$ & & & $5.056 * *$ & & & 2.784 * & & $316 * *$ & & & $2.591 *$ & \\
\hline
\end{tabular}

Table 2 shows that personality accounted for $9.7 \%$ variance in the Tendency towards Cheating, which is significant $(\mathrm{F}(5,226)=5.056, \mathrm{p}<.001)$. Agreeableness $(\beta=-.22$, $\mathrm{t}(231)=-3.256, \mathrm{p}=.001)$ and Openness to Experience $(\beta=-.142, \mathrm{t}(231)=-2.087, \mathrm{p}=.038)$ are significant predictors of Tendency towards Cheating . 
For the variable of Tendency towards Dishonesty in Assignment, personality accounted for $5.6 \%$ variance, which is significant $(\mathrm{F}(5,226)=2,784, \mathrm{p}=.018)$. Openness to Experience $(\beta=-.147, \mathrm{t}(3)=-2.117, \mathrm{p}=.035)$ is a significant predictor of Tendency towards dishonesty in Assignments.

When we look at the variable of Tendency towards dishonesty in Research \& Reports, personality accounted for $10.1 \%$ variance, which is significant $(F(5,226)=5.316$, $\mathrm{p}<.001)$. Conscientiousness $(\beta=-.193, \mathrm{t}(231)=-2.790, \mathrm{p}=.006)$ and Openness to Experience $(\beta=-.145, \mathrm{t}(231)=-2.145, \mathrm{p}=.033)$ are significant predictors of Tendency towards dishonesty in Research and Reports.

The next factor on Academic Dishonesty is Tendency towards dishonesty in Ascriptions where personality significantly accounts for $5.2 \%(\mathrm{~F}(5,226)=2.591, \mathrm{p}=.026)$. Extraversion $(\beta=-.141, \mathrm{t}(231)=-2.087, \mathrm{p}=.038)$ only significantly predicts this particular tendency of dishonesty.

Table 3

Multiple regression analysis of the Big Five Personality in predicting the dishonesty by influencing teachers

\begin{tabular}{|l|c|c|c|}
\hline & \multicolumn{1}{|c|}{ Dishonesty by Influencing Teachers } \\
\hline Variable & $B$ & $S E B$ & $\beta$ \\
\hline Neuroticism & -.007 & .050 & -.009 \\
\hline Extraversion & -.123 & .057 & $-.138^{*}$ \\
\hline Openness & -.141 & .047 & $-.200 * *$ \\
\hline Agreeableness & -.166 & .052 & $-.208^{* *}$ \\
\hline Conscientiousness & .040 & .052 & .050 \\
\hline \multicolumn{2}{|c|}{$\boldsymbol{R}^{2}$} & \multicolumn{3}{c|}{$7.618^{* *}$} \\
\hline \multicolumn{1}{|c|}{$\boldsymbol{F}<.05 * * p<.01$} & & \\
\hline
\end{tabular}

Table 3 shows that personality accounted for $13.9 \%$ variance in the variable of Dishonesty by Influencing Teachers, which is significant $(\mathrm{F}(5,226)=7.618, \mathrm{p}<.001)$, highest uptill now in all types of dishonesties studied in this research paper. Three personality factors, that are Extraversion $(\beta=-.138, \mathrm{t}(231)=-2.145, \mathrm{p}=.033)$, Agreeableness $(\beta=-.208, \mathrm{t}(231)=-3.178, \mathrm{p}=.002)$ and Openness to Experience $(\beta=-$ $.200, \mathrm{t}(231)=-3.023, \mathrm{p}=.003)$ are found to be significant predictors of Dishonesty by Influencing Teachers.

\section{Discussion}

Academic dishonesty has been an area of deep concern and literature since the last century has been focusing on it. The present study has also been an attempt to see the personality predictors of academic dishonesty. The result showed that Openness to Experience is significantly negatively correlated with all factors of academic dishonesty, 
and also it is a significant predictor of the tendency towards cheating, towards dishonesty in assignments, research and reports and influencing teachers. People who score high on Openness to Experience are imaginative and broadminded. These people are usually more concerned with learning, have a higher desire for understanding concepts; therefore they have fewer predispositions for being academically dishonest. ${ }^{18}$

Agreeableness was found to be a significant predictor of tendency towards cheating and influencing teachers. It is significantly negatively correlated with these variables too, along with tendency for dishonesty in assignments and ascriptions. Researches have also found negative correlation between agreeableness and cheating. ${ }^{19}$ Since modesty and morality are the sub-traits of agreeableness, it is understandable that people who are more agreeable have high academic integrity. Moreover, individuals who are more agreeable tend to be optimistic and tactful so they do not need to resort to unethical and dishonest behavior for academic achievement; rather they keep a positive approach to achieve their goals. People who score less on agreeableness tend to be non-cooperative, and put their own interests before others. For them submitting an assignment that was made by someone else's effort, or doing some plagiarism is not a big deal. This personality variable has been found to be a predictor of religiosity ${ }^{20}$ too, which teaches people not to be dishonest.

Extraversion was found to be a significant predictor of tendency towards dishonesty in ascriptions and influencing teachers. It was also found to be negatively correlated with these two together with dishonesty in research and reports. Aslam and Nazir ${ }^{21}$ conducted a study in Northern Pakistan, and found that students, who scored high on Extraversion, recommended high level penalty for (other) people who are involved in act of academic dishonesty. In the present study a negative relationship between extraversion and academic dishonesty was unveiled, meaning the more introverted a person is, the less judgmental he would be in the context of academic dishonesty. This can be presumed because the items in the questionnaire were not about whether the participants have performed this act or not, but rather if they find it appropriate if someone else does it. Tiegerand Barron-Tieger ${ }^{22}$ asserted that introverts usually need more time to absorb and understand new information and then compare it to their schemas before responding or reaching to the conclusion. Introverted people need to process things thoroughly to reflect on circumstances and to develop their ideas. This might be the reason that people who scored high on introversion did not judge those who are involved in academic dishonesty.

\footnotetext{
${ }^{18}$ Day, N.E, Hudson, D, Dobies, P.R, and Waris, R, " Students or situation? Personality and classroom context as predictors of attitudes about business school cheating." Social Psychology of Education 14, No.2 (2001): 261-282.

${ }^{19}$ Eshet, Y, Peled, Y, Grinautski, and Barczyk, C, "Can you explain this? Personality and willingness to commit various acts of academic misconduct." Journal of Communication \& Computer 10, (2013): 1042-1046.

${ }^{20}$ McCullough, M.E., Tsang, J. and Brion, "Personality Traits in Adolescence as Predictors of Religiousness in Early Adulthood: Findings From the Terman Longitudinal Study." Personality and Social Psychology Bulletin 29, No.8 (2003): 980-991. DOI: 10.1177/0146167203253210

${ }^{21}$ Aslam, M.S, and Nazir, M.S, "The Impact of Personality Traits on Academic Dishonesty among Pakistan Students." The Journal of Commerce 3, No.2 (2011): 50-61.

${ }^{22}$ Tieger, P. D, and Barron-Tieger,B, "Do what you are: Discover the perfect career for you through the secrets of personality type." (2nd ed.)., (New York: Little, Brown and Company, 1995).
} 
On the contrary, another reason could be the introvert's tendency to avoid conflict ${ }^{23}$ by being passive aggressive instead of expressing their aggression overtly. Since dishonesty in research and reports can be done by apparently staying passive, introverted people might opt for it rather than directly confronting teachers or fellow students. It can also be speculated that introverted people might be able to gain sympathy from the teachers. Moreover, it should also be considered that "sometimes introverts act extroverted and vice versa" ${ }^{24}$.

Conscientiousness was negatively correlated with dishonesty in cheating, assignments and research and reports, but only predicted dishonesty in research and report. The ability of being conscientious allows a person to predict and discriminate between ethical and unethical behavior which reduces the chance of them being dishonest. ${ }^{25}$ Conscientious people are highly organized and are found to be better prepared academically and so they have lesser need to cheat. Since they are better able to regulate their behavior ${ }^{26}$ and are more achievement oriented, responsible and honest, they are better able to resist cheating. ${ }^{27}$ Research on personality predictors of religiosity found that highly conscientious people might be more likely to stay faithful to religious activities. ${ }^{28}$ Conscientiousness motivates people to abide by rules, therefore, they have a strong sense of morality. This suggests that religiosity among conscientious people stops them from indulging in dishonest behavior. With reference to academic dishonesty, it can be concluded that the more conscientious the students are, the more honest they would be.

In the past, researches have given some mixed up results about the variable of Neuroticism. Some researches $\mathrm{s}^{29,30}$ found positive correlation between this variable and academic dishonesty, that is the more neurotic the person is, the more dishonest he tends to be. Whereas, in other researches, ${ }^{31,32}$ no relationship or impact of neurotic personality

${ }^{23}$ Cain, S, "Quiet: The power of introverts in a world that can’t stop talking." (New York: Crown Publishing, 2012).

${ }^{24}$ Laney, M.O, "The introvert advantage: How to thrive in an extrovert world." ( New York: Workman Publishing, 2001).

${ }^{25}$ Robinson, S. L. and Greenburg, J, "Employees Behaving Badly: Dimensions, Determinants, and Dilemmas in the Study of Workplace Deviance." Trends in organizational behavior, C. L. Cooper \& D. M. Rousseau (Eds.), (Chichester: John Wiley and Sons, 1998): 1-30.

${ }^{26}$ Jensen-Campbell, L.A, and Graziano, W.G, "The two faces of temptation: Differing motives for self-control." Merrill-Palmer Quarterly 15, No.3 (2005): 287-314.

${ }^{27}$ Barrick, M. R, and Mount, M. K, "The Big Five Personality Dimensions and Job Performance:A MetaAnalysis.” Personnel Psychology 44, No.1 (1991): 1-26.

${ }^{28}$ McCullough, M.E., Tsang, J. and Brion, "Personality Traits in Adolescence as Predictors of Religiousness in Early Adulthood: Findings From the Terman Longitudinal Study.” Personality and Social Psychology Bulletin 29, No.8 (2003): 980-991. DOI: 10.1177/0146167203253210

${ }^{29}$ Eshet, Y, Peled, Y, Grinautski, and Barczyk, C, "Can you explain this? Personality and willingness to commit various acts of academic misconduct." Journal of Communication \& Computer 10, (2013): 1042-1046.

${ }^{30}$ Williams,K.M, Nathanson, C, and Pailhus,D.L, "Identifying and Profiling Scholastic Cheaters: Their Personality, Cognitive Ability and Motivation." Journal of Experimental Psychology 16, No.3 (2010): 293-307.

${ }^{31}$ Christine, Z.J, and James, C.A, "Personality traits and academic attributes as determinants of academic dishonesty in accounting and non-accounting college majors." In the Proceeding of 15th Annual Meeting of American Society of Business and Behavioral Sciences (ASBBS) 15, (USA,Las Vegas, 23-24 Feb. 2008 ): 604-616.

${ }^{32}$ Aslam, M.S, and Nazir, M.S, "The Impact of Personality Traits on Academic Dishonesty among Pakistan Students." The Journal of Commerce 3, No.2 (2011): 50-61. 
on academic dishonesty was found. Neuroticism is associated with instability in one's thought processes which explains the inconsistency in findings relating to neuroticism and academic dishonesty. Owing to the negative emotional state manifesting neuroticism, at times individuals might withdraw and become indifferent to the consequences of poor result and at other times, their anxiety and fear can make them desperate and as a result they might indulge in cheating and other dishonest behavior. In the present study also Neuroticism had no relationship or made no prediction about any type of academic dishonesty. Since these people are emotionally unstable, we do not find any stable relationship between the variables as well.

Overall, it is seen that the big five personality is a good predictor of different types of dishonest behavior seen in the academic context in university students of Karachi, Pakistan. The more Open to Experience, Agreeable, Extraverted and Conscientious students are, the lesser is the chance that they will indulge in dishonest behavior. The finding that students indulge in dishonest behavior in their academic activities is a discouraging scenario, especially when they also find reasons to continue with such activities. ${ }^{33}$ However, knowing that certain personalities are more vulnerable and better predictors of academic dishonesty than others makes the situation hopeful. A lot of student counseling programs can be held where these students can be trained for better methods of dealing with examination situation can be done. What is needed is to see how other demographic variables as well as situational variables play a role in academic dishonesty. Future researches are needed in this context. Also the role of punishment or counseling in reducing this dishonest behavior should also be seen from both the teacher's and student's perspective. Also this study was limited to the sample of Karachi, therefore finding can be generalized to the similar population.

${ }^{33}$ Jensen, L. A, Arnett, J. J, Feldman, S. S, \&Cauffman, E, "It's wrong, but everybody does it: Academic dishonesty among high school and college students." Contemporary Educational Psychology 27, No.2 (2002): 209-228. 